\title{
The eyes have it: duret haemorrhage after traumatic subdural haematoma
}

\author{
Sean Lance $10,{ }^{1,2}$ Chi Hau Tan, ${ }^{3}$ Ian Rosemergy ${ }^{2}$
}

${ }^{1}$ Department of Medicine, University of Otago Wellington, Wellington, New Zealand ${ }^{2}$ Neurology, Capital and Coast District Health Board, Wellington, New Zealand ${ }^{3}$ Neurosurgery, Capital and Coast District Health Board, Wellington, New Zealand

\section{Correspondence to} Dr Sean Lance;

Sean.Lance@ccdhb.org.nz

Accepted 19 August 2020

\section{DESCRIPTION}

A 51-year-old woman with no significant medical history was found collapsed at work having sustained a head strike. She was evaluated at her local hospital. Glasgow Coma Scale was 12 (E3 V3 M6). Pupils were equal and reactive. Eye movements were normal. CT of the brain revealed a large left-sided acute subdural haematoma with 12 $\mathrm{mm}$ midline shift (figure 1). She was intubated and transferred to Wellington Hospital where she had emergency haematoma evacuation.

CT of the brain performed the next day showed resolution of the subdural haematoma and midline shift (figure 1). After extubation, she was noted to have new extraocular movement abnormalities.

Examination revealed a left third-nerve palsy. At rest the eye was 'down and out' with left ptosis, severe restriction of left eye adduction and also vertical eye movements. Additionally, there was a right internuclear ophthalmoplegia with restricted right eye adduction and corresponding abduction nystagmus of the left eye. Photographs demonstrating her eye movements are shown in figure 2 and a video of eye movements is included in video 1 .

MRI of the brain (figure 1) showed two diffusion restricted lesions corresponding to the left oculomotor nucleus in the midbrain and the right medial longitudinal fasciculus in the pons. Susceptibilityweighted imaging revealed signal drop out consistent with acute haemorrhage in these areas. Retrospective review of the initial CT of the brain did not show any evidence of haemorrhage in the brainstem and a cerebral angiogram was performed which was normal.

The consensus was that these represented Duret haemorrhages secondary to transtentorial

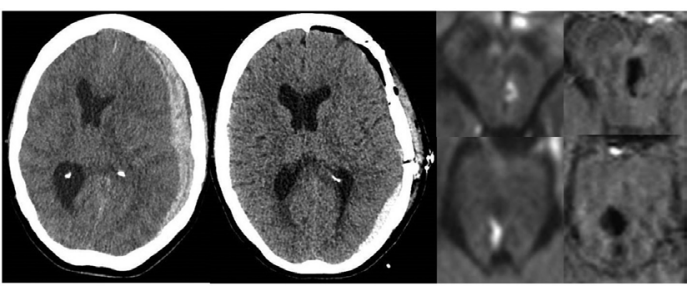

(C) BMJ Publishing Group Limited 2020. No commercial re-use. See rights and permissions. Published by BMJ.

To cite: Lance $\mathrm{S}$, Tan $\mathrm{CH}$, Rosemergy I. BMJ Case Rep 2020;13:e237841. doi:10.1136/bcr-2020237841
Figure 1 Imaging - (A) Axial CT of the brain imagespre (left) and post (right) drainage of left-sided subdural haematoma with midline shift. (B) Postoperative MRI of the brain-diffusion-weighted imaging (left) and susceptibility-weighted imaging (right) of midbrain (top) and pons (bottom) showing lesions at the level of the left oculomotor nucleus and the right medial longitudinal fasciculus, respectively.

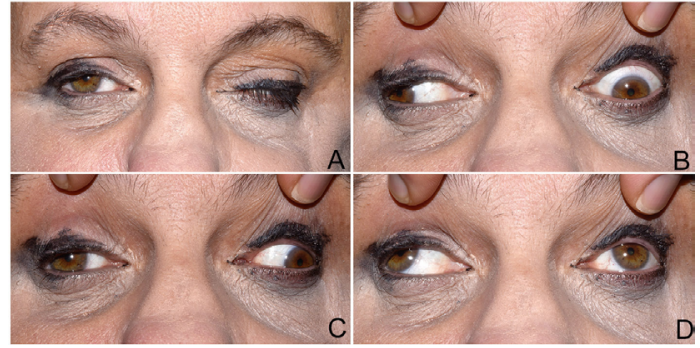

Figure 2 Eye movements clockwise from top left: (A) looking straight ahead; (B) looking right; (C) looking left; (D) looking up and to the right.

brain herniation as a result of the acute subdural haematoma.

The patient was able to be discharged home after a short period of rehabilitation with persisting restricted eye movements but no significant functional impairment.

Duret haemorrhage, also known as secondary brainstem haemorrhage, occurs as a result of transtentorial herniation of the brain in the context of acute trauma (eg, subdural haematoma). ${ }^{12}$ It is hypothesised to occur as a result of the downward pressure shearing small mobile blood vessels within the brainstem from the relatively immobile basilar artery. $^{2}$ Surgical decompression can also result in haemorrhage from reperfusion injury. ${ }^{2}$ Due to their location, there is an association with poor prognosis of death or severe neurological disability, which often results in earlier withdrawal of life-sustaining therapies. ${ }^{2}$

Our case highlights the caution required when assessing prognosis in patients with Duret haemorrhage. Not only did she survive, but also her neurological disability was not debilitating-unusual in Duret haemorrhage. Given the normal eye movements on presentation and lack of haemorrhage on

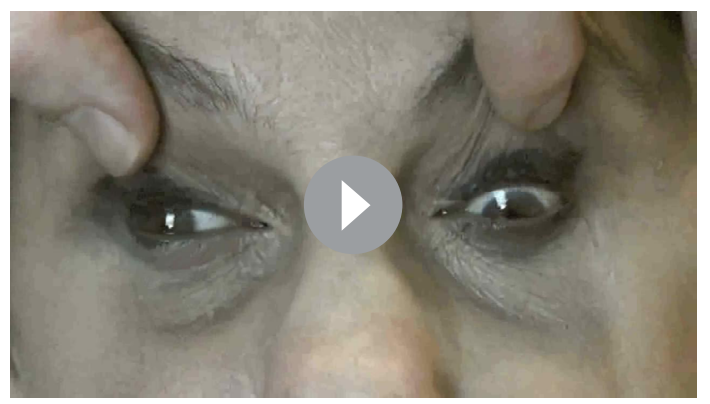

Video 1 Recording of eye movements demonstrating a left third -nerve palsy along with a right internuclear ophthalmoplegia 


\section{Learning points}

Confusing eye signs usually localise to the brainstemalways consider more than a single lesion.

- Duret haemorrhage is not universally fatal.

- Post decompression Duret haemorrhage is thought to have a better prognosis and this should be considered when making clinical decision about ongoing management of these patients.

the initial CT of the brain, we suspect that in her case the haemorrhage was a small reperfusion injury following her decompressive surgery. This may have contributed to her better prognosis and hence similar findings in other patients may influence and help guide clinical decision-making.

Acknowledgements We would like to acknowledge Louise Goosens, the medical photographer at Capital and Coast District Health Board for her fantastic photographs. We would also like to acknowledge Dr Evan Jolliffe, Neurologist, for his help with manuscript preparation.

Contributors All of the authors were involved with the care of the patient during her stay in hospital. All of the authors were involved with the planning and conception of the manuscript. SL prepared the draft manuscript with editing from $\mathrm{CHT}$ and IR.

Funding The authors have not declared a specific grant for this research from any funding agency in the public, commercial or not-for-profit sectors.

Competing interests None declared.

Patient consent for publication Obtained.

Provenance and peer review Not commissioned; externally peer reviewed.

\section{ORCID iD}

Sean Lance http://orcid.org/0000-0002-5559-6572

\section{REFERENCES}

1 Moore SA, Mittal MK, Rabinstein AA. Duret hemorrhage following subdural hematoma evacuation. JAMA Neurol 2013;70:518.

2 Stiver SI, Gean AD, Manley GT. Survival with good outcome after cerebral herniation and Duret hemorrhage caused by traumatic brain injury. J Neurosurg 2009:110:1242-6.

Copyright 2020 BMJ Publishing Group. All rights reserved. For permission to reuse any of this content visit

https://www.bmj.com/company/products-services/rights-and-licensing/permissions/

BMJ Case Report Fellows may re-use this article for personal use and teaching without any further permission.

Become a Fellow of BMJ Case Reports today and you can:

- Submit as many cases as you like

- Enjoy fast sympathetic peer review and rapid publication of accepted articles

- Access all the published articles

- Re-use any of the published material for personal use and teaching without further permission

Customer Service

If you have any further queries about your subscription, please contact our customer services team on +44 (0) 2071111105 or via email at support@bmj.com.

Visit casereports.bmj.com for more articles like this and to become a Fellow 